\title{
Present status of the millipede fauna of Hungary, with a review of three species of Brachyiulus Berlése, 1884 (Diplopoda)
}

\author{
Z. KORSÓS ${ }^{1,2} \&$ E. LAZÁNYI ${ }^{2}$ \\ ${ }^{1}$ Zoltán Korsós, Institute for Biology, University of Veterinary Medicine Budapest, Rottenbiller u. 50, \\ H-1077 Budapest, Hungary, E-mail: korsos.zoltan@univet.hu \\ ${ }^{2}$ Zoltán Korsós \& Eszter Lazányi, Department of Zoology, Hungarian Natural History Museum, Baross u. 13, \\ H-1088 Budapest, Hungary, E-mail: lazanyi.eszter@nhmus.hu
}

\begin{abstract}
Since 2005, the last comprehensive species list of the millipedes of Hungary, several new species to the fauna have been approved. Here we provide an updated summary of all Hungarian Diplopoda, comprising altogether 107 species. Brachyiulus pusillus (Leach, 1815) and Chondrodesmus riparius Carl, 1914, based on recent collections, are considered as new to the fauna of Hungary. We give special remarks to the following taxa: Julus curvicornis Verhoeff, 1899, Typhloiulus polypodus (Loksa, 1960), Hungarosoma bokori Verhoeff, 1928, Heteracrochordum evae (Loksa, 1960), Ochogona spp., Haasea hungarica (Verhoeff, 1928), Mastigona spp., and some Polydesmidae. In addition, the taxonomical relationship between B. bagnalli (Brolemann, 1924), B. lusitanus (Verhoeff, 1898), and B. pusillus is discussed in detail. With 21 figures.
\end{abstract}

Keywords. Brachyiulus pusillus, Chondrodesmus riparius, faunal list, new occurrences.

\section{INTRODUCTION}

$\mathrm{T}$ he millipede fauna (Diplopoda) of the territory of Hungary was summarized several times in the past 25 years by Korsós (Korsós 1994, 1998, 2001, 2005). In 2005, on a poster for the $13^{\text {th }}$ International Congress of Myriapodology, Bergen, Norway, the number given was 101 species (Korsós 2005), which testified a gradual increase depending on the research efforts. Since then, four new species were subsequently added to the fauna of the country: $C$. caeruleocinctus (Wood, 1864) in Bogyó \& Korsós (2010), Megaphyllum silvaticum (Verhoeff, 1898) in Lazányi \& Korsós (2010), Cylindroiulus burzenlandicus Verhoeff, 1907 and Leptoiulus liptauensis (Verhoeff, 1899) in Bogyó et al. (2012). In our presentation during the $18^{\text {th }}$ International Congress of Myriapodology, Budapest (Korsós \& Lazányi 2019) we discussed the occurrences of 106 species, including the recently collected Brachyiulus pusillus (Leach, 1815) and Chondrodesmus riparius
Carl, 1914. These are formally added here to the species list of Hungarian millipedes. In the present paper, we also change the list according to formerly omitted literature records. Thus, we remove Mastigona vihorlatica (Attems, 1899) [= M. bosniensis (Verhoeff, 1897) by Hauser 2004], and add Ochogona phyllophaga (Attems, 1899) and Polydesmus subscabratus Latzel, 1884.

\section{LIST OF MILLIPEDES (DIPLOPODA) OF HUNGARY}

In the followings, we give an updated list of the millipede fauna of Hungary, with 107 species in total. In contrast to the earlier species lists (Korsós 1994, 1998) we do not include the subspecific category as subspecies are sometimes based on uncertain characters. We follow the systematic arrangement of Diplopoda by Shear (2011) down to the family level; lower taxa are presented in alphabetic order. In a few cases, status changes in species taxonomy are 
mentioned in parentheses, as compared to the species list in Korsós (1998). New locality records are also given for three species. An asterisk (*) marks the species which have already published data from Hungary, but not included in the earlier faunal lists, two asterisks (**) mark the species presented here as new to the Hungarian fauna. Superscript numbers $\left({ }^{\mathrm{n}}\right)$ refer to the remarks section of the present paper.

\section{POLYXENIDA}

Polyxenidae

1. Polyxenus lagurus (Linnaeus, 1758)

\section{GLOMERIDA}

Glomeridellidae

2. Glomeridella minima (Latzel, 1884)

Glomeridae

3. Glomeris hexasticha Brandt, 1833

4. Glomeris klugii Brandt, 1833 (= G. conspersa C. L. Koch, 1847 in Korsós 1998)

5. Glomeris ornata C. L. Koch, 1847

6. Glomeris pustulata (Fabricius, 1781)

7. Glomeris tetrasticha Brandt, 1833 (= G. connexa C. L. Koch, 1847 in Korsós 1998)

8. Haploglomeris multistriata (C. L. Koch, 1844)

9. Trachysphaera costata (Waga, 1857)

10. Trachysphaera gibbula (Latzel, 1884)

11. Trachysphaera schmidtii Heller, 1858

POLYZONIIDA

Polyzoniidae

12. Polyzonium germanicum Brandt, 1837

JULIDA

Blaniulidae

13. Archiboreoiulus pallidus (Brade-Birks, 1920)
14. Blaniulus guttulatus (Fabricius, 1798)

15. Boreoiulus tenuis (Bigler, 1913)

16. Choneiulus palmatus (Nĕmec, 1895)

17. Cibiniulus phlepsii (Verhoeff, 1897)

18. Nopoiulus kochii (Gervais, 1847)

19. Proteroiulus fuscus (Am Stein, 1857)

Julidae

20. Allajulus dicentrus (Latzel, 1884)

21. Allajulus groedensis (Attems, 1899)

22. Brachyiulus bagnalli (Brolemann, 1924) ${ }^{10}$

23. Brachyiulus lusitanus Verhoeff, $1898^{10}$

24.**Bachyiulus pusillus (Leach, 1815) ${ }^{10}$

25. Cylindroiulus abaligetanus Verhoeff, 1901

26. Cylindroiulus arborum Verhoeff, 1928

27. Cylindroiulus boleti (C. L. Koch, 1847)

28. Cylindroiulus burzenlandicus Verhoeff, 1907

29. Cylindroiulus caeruleocinctus (Wood, 1864)

30. Cylindroiulus horvathi (Verhoeff, 1897)

31. Cylindroiulus latestriatus (Curtis, 1845)

32. Cylindroiulus luridus (C. L. Koch, 1847)

33. Cylindroiulus meinerti (Verhoeff, 1891)

34. Cylindroiulus parisiorum (Broelemann \& Verhoeff, 1896)

35. Cylindroiulus truncorum (Silvestri, 1896)

36. Enantiulus nanus (Latzel, 1884)

37. Enantiulus tatranus (Verhoeff, 1907)

38. Julus curvicornis Verhoeff, $1899^{1}$

39. Julus scandinavius Latzel, 1884

40. Julus scanicus Lohmander, 1925

41. Julus terrestris Linnaeus, 1758

42. Kryphioiulus occultus (C. L. Koch, 1847) 
43. Leptoiulus baconyensis (Verhoeff, 1899)

44. Leptoiulus cibdellus (Chamberlin, 1921)

45. Leptoiulus liptauensis (Verhoeff, 1899)

46. Leptoiulus proximus (Nĕmec, 1896)

47. Leptoiulus saltuvagus (Verhoeff, 1898)

48. Leptoiulus simplex (Verhoeff, 1894)

49. Leptoiulus trilineatus (C.L.Koch, 1847)

50. Leptoiulus trilobatus (Verhoeff, 1894)

51. Leptoiulus tussilaginis (Verhoeff, 1907)

52. Megaphyllum bosniense (Verhoeff, 1897)

53. Megaphyllum projectum Verhoeff, 1894

54. Megaphyllum silvaticum (Verhoeff, 1898)

55. Megaphyllum transsylvanicum (Verhoeff, 1897)

56. Megaphyllum unilineatum (C. L. Koch, 1838)

57. Mesoiulus paradoxus Berlése, 1886

58. Ommatoiulus sabulosus (Linnaeus, 1758)

59. Ophyiulus pilosus (Newport, 1842)

60. Pachypodoiulus eurypus (Attems, 1894)

61. Styrioiulus pelidnus (Latzel, 1884)

62. Styrioiulus styricus (Verhoeff, 1896)

63. Typhloiulus polypodus (Loksa, 1960) ${ }^{2}$

64. Unciger foetidus (C. L. Koch, 1838)

65. Unciger transsilvanicus (Verhoeff, 1899)

66. Xestoiulus imbecillus (Latzel, 1884)

67. Xestoiulus laeticollis (Porat, 1889)

Nemasomatidae

68. Nemasoma varicorne C. L. Koch, 1847

CALLIPODIDA

Dorypetalidae

69. Dorypetalum degenerans (Latzel, 1884)

\section{CHORDEUMATIDA}

Chordeumatidae

70. Chordeuma sylvestre C. L. Koch, 1847

71. Melogona broelemanni (Verhoeff, 1897)

72. Melogona transsilvanica (Verhoeff, 1897)

Hungarosomatidae

73. Hungarosoma bokori Verhoeff, $1928^{3}$

Trachygonidae

74. Heteracrochordum evae (Loksa, 1960) ${ }^{4}$ (= Acrochordum evae Loksa, 1960 in Korsós 1998)

Craspedosomatidae

75. Craspedosoma raulinsii Leach, 1814

76. Ochogona caroli (Rothenbühler, 1900) ${ }^{5}$

77. Ochogona elaphron (Attems, 1895)

78. Ochogona phyllophaga (Attems, 1899) ${ }^{5}$

79. Ochogona triaina (Attems, 1895)

Haaseidae

80. Haasea flavescens (Latzel, 1884)

81. Haasea hungarica (Verhoeff, 1928) ${ }^{6}$

82. Hylebainosoma tatranum Verhoeff, 1899

Mastigophorophyllidae

83. Haploporatia eremita Verhoeff, 1909

84. Mastigona bosniensis (Verhoeff, 1897) ${ }^{7}$

85. Mastigona mutabilis (Latzel, 1884) ${ }^{7}$

86. Mastigona transsylvanica (Verhoeff, 1897) ${ }^{7}$

POLYDESMIDA

Chelodesmidae

87.** Chondrodesmus riparius Carl, $1914^{8}$

Paradoxosomatidae

88. Oxidus gracilis (C. L. Koch, 1847) 
89. Stosatea italica (Latzel, 1886)

90. Strongylosoma stigmatosum (Eichwald, 1830)

Oniscodesmidae

91. Amphitomeus attemsi (Schubart, 1934)

Pyrgodesmidae

92. Cynedesmus formicola Cook, 1896

93. Poratia digitata (Porat, 1889)

Polydesmidae

94. Brachydesmus attemsii Verhoeff, 1895

95. Brachydesmus dadayi Verhoeff, $1895^{9}$

96. Brachydesmus superus Latzel, 1884

97. Brachydesmus troglobius Daday, $1889^{9}$

98. Polydesmus collaris C. L. Koch, 1847

99. Polydesmus complanatus (Linnaeus, 1761)

100. Polydesmus denticulatus C. L. Koch, 1847

101. Polydesmus edentulus C. L. Koch, 1847

102. Polydesmus germanicus Verhoeff, 1896

103. Polydesmus monticola Latzel, 1884

104. Polydesmus polonicus Latzel, 1884

105. Polydesmus schaessburgensis Verhoeff, $1898^{9}$

106."Polydesmus subscabratus Latzel, $1884^{9}$

107. Polydesmus transylvanicus Daday, $1889^{9}$

\section{REMARKS TO THE SPECIES LIST}

\section{${ }^{1} J u l u s$ curvicornis Verhoeff, 1899}

The species was described by Verhoeff from present-day Hungary ("Bükk-Gebirge, Oberungarn", Verhoeff 1899b), and mentioned several times by Karel Tajovský that it should occur near the East Slovakian border (Tajovský pers. comm.). We have recently found a sample in the HNHM collection, originated from the Institute of Systematic Zoology, University of Budapest, with one adult and one juvenile male and an adult female (Szalajka valley, Bükk Mts, 29 June 1951). The tube contained a simple handwritten label (“Julus curv.") by Imre Loksa (1923-1992), former professor at the university. The male gonopods are in complete agreement with the drawings by Verhoeff (1899b, 1928).

\section{${ }^{2}$ Typhloiulus polypodus (Loksa, 1960)}

The species has been described by Loksa (1960) as Allotyphloiulus polypodus, from the Forrás Cave near Lillafüred, Bükk Mts., northeastern Hungary. Its generic allocation is still undecided. Vagalinski et al. (2015) in their revision listed it in Typhloiulus Latzel, 1884, whereas in the Millibase it is under the genus Allotyphloiulus Verhoeff, 1905 (Sierwald \& Spelda 2018). (It is completely missing from the Fauna Europaea database.) For a long time, the species was only known from the type locality, when Mock et al. (2002) found a female identified as Typhloiulus cf. polypodus in the Gombasecká Cave in the Slovak Karst.

\section{${ }^{3}$ Hungarosoma bokori Verhoeff, 1928}

This species was described by Verhoeff (1928) based on a single female from the Abaliget Cave, South Hungary, collected by Elemér Bokor (1887-1928) Hungarian cave zoologist. He gave a detailed description of the specimen's eyes and body segments with paraterga and setae, with figures. Verhoeff (1928) also speculated about the systematic position of this chordeumatidan: according to his opinion the genus Hungarosoma, although related to Brachychaeteuma, finds its nearest relative in Japan, in the genus Macrochaeteuma, showing a peculiar connection between the millipede fauna of Southeast Europe and Asia (Verhoeff 1928). Several years after the description of another species, Hungarosoma inexpectatum Ceuca, 1967, Ceuca (1974) erected the family Hungarosomatidae for the two species alone. This was generally not accepted, and Hungarosoma was 
later erroneously assigned to Anthroleucosomatidae (Hoffman 1980, Enghoff 2013). Following all these, for a long time Hungarosoma bokori was considered a unique and endemic member of the Hungarian fauna, a troglobiont (Korsós 1994, 1998), and it still stands as such in the databases of Fauna Europaea (Enghoff 2013) and Millibase (Sierwald \& Spelda 2018). Mock et al. $(2014,2016)$ finally presented a detailed description of a freshly collected male, as well as a careful study of all available museum material. They even carried out a molecular research, in which $H$. bokori came out as an independent lineage supporting the validity of the family Hungarosomatidae (Mock et al. 2016).

However, in a more recent paper Antić et al. (2018) called for attention to a curious similarity between the illustrations of Ceratosoma cervinum Verhoeff, 1899 (Verhoeff 1899a: figs 19-23; and Mršić 1987: p. 67, fig. 10 I, J), and the illustrations of Hungarosoma bokori (Mock et al. 2016: pp. 245,247 , figs 15,16$)$. They concluded that they all show the male gonopods of the same species, however schematic are the figures of Ceratosoma cervinum Verhoeff, 1899 (now accepted as Ochogona cervinum (Verhoeff, 1899) (Antić et al. 2018)). They did not formally establish a synonymy, and because their observation is based only on the drawings, here we still follow the consensus taxonomy and consider $H$. bokori a good species in its own status. In agreement with Hal'ková \& Mock (2018) we believe that a proper synonymy can only be proven if the original specimens of Ceratosoma cervinum sensu Verhoeff are compared under the microscope to the $H$. bokori material.

Our concept on the geographic distribution of $H$. bokori has nevertheless changed substantially, since the extensive collections by our Czech and Slovakian colleagues showed that its occurrence surpasses the Carpathian Basin by far (see the map in Mock et al. 2016: fig. 19). Hence its endemic status to Hungary (Korsós 1998) is now revised.

\section{${ }^{4}$ Heteracrochordum evae (Loksa, 1960)}

The species was originally described by Loksa (1960) from a beech forest near Bánkút, Bükk Mts, north-eastern Hungary, as a new subgenus Heteracrochordum Loksa, 1960 in the genus Acrochordum Attems, 1899. There is one female specimen found in the HNHM, with only a species label handwritten by Loksa but without further details, which we believe could be part of the syntype series. In Loksa's paper, four specimens are listed as part of the type series, one female from 15 September 1949, and one male and two juveniles from 20 July 1954, from the same locality (Loksa 1960), all of them supposedly deposited in the Department of Zoosystematics, Eötvös Loránd University. Since those specimens could not be located, we consider the HNHM specimen as the female syntype.

Heteracrochordum is accepted now as a valid genus (Sierwald \& Spelda 2018, Mock et al. 2019), known only by its type species, which is considered as endemic to the Carpathian Basin (Korsós 1998). The family Trachygonidae is supposedly under revision by Mock et al. (2019), as they said in the presentation during the $18^{\text {th }}$ International Congress of Myriapodology in Budapest. They have found new records of Heteracrochordum evae in two distinct regions in Slovakia (Driencany, Burda Mts in Mock et al. 2019), representing the northernmost limits of the family distribution.

\section{${ }^{5}$ Ochogona species}

We accept four species as occurring in Hungary, which are discussed below:

Ochogona caroli (Rothenbühler, 1900): Material studied: Bakony Mts, Zirc, Pintér Hill, 1941.X.19, leg. L. Szalay \& I. Kovács, det. L. Szalay (3215/1943, five vials, gonopods separated: My. 1331, 1333, 1334, 1336, 1337); Zirc, Pintér Hill, 1941.X.21, leg. L. Szalay \& I. Ko- 
vács, det. L. Szalay (3215/1943, gonopods separated in vial: My. 1338); Bakony Mts, Miklós Pál Hill, 1965.X., leg. I. Loksa \& Zs. Szombathelyi, det. I. Loksa.

Ochogona elaphron (Attems, 1895): Material studied: Köszegi Mts., 1937.XI.1, leg. A. Visnya Aladár, det 3160/1942, det. L. Szalay L. (3160/1942, My. 1330), revid. I. Loksa (200/1955); Köszegi Mts., 1938.XI.2., leg. A. Visnya, det. L. Szalay (3162/1942, My 1332\& 1335).

Ochogona triaina (Attems, 1895): Material studied: Köszegi Mts., 1937.XI.1, leg. Bpesti Egyet. Állatrendsz. Int., det. L. Szalay (3160/1942, My 1329), 1 male and 1 female,gonopods in genitalia vial.

With these three species we follow Szalay $(1942,1944)$ who considered them separate species as it can be seen on the labeling of the HNHM specimens. Loksa (1968) for Szalay's Ochogona caroli specimens from Pintér Hill, 1941, and for his own 1968 Miklós Pál Hill sample described $O$. c. ssp. hungaricum, as well as another ssp. somloense from Somló Hill (Loksa 1968). The tubes in the HNHM contain only hand-written labels by Loksa (in the case of Somló Hill with the name "Ceratosoma caroli evae", Somló 67.X.); however we consider them as part of the original syntype series of $O$. c. somloense. Together with Verhoeff's Ceratosoma caroli ssp. nubium Verhoeff, 1921, we do not differentiate them from the nominal species Ochogona caroli.

In the collection material there are $O$. elaphron and $O$. triaina vials with labels suggesting their co-occurrence (especially because they seem to be collected at once). Dr. László Szalay had worked with the genus in details; in his material gonopods are dissected, so here we rely on his results (Szalay 1942) and accept the occurrence of both species in Hungary.

Ochogona phyllophaga (Attems, 1899): This fourth species we add here to the species list of millipedes of Hungary. Antić \& Akkari
(2020) called our attention to this species, of which the original literature record by Attems (1899: p. 315) was unfortunately overlooked by us. Attems in his description of Atractosoma phyllophagum Attems, 1899, listed "St. Gotthard in Ungarn, ganz nahe der steirischeu Grenze" as type locality of the species, which clearly corresponds to Szentgotthárd, a small town in the westernmost part of present-day Hungary. We hope to find new specimens of this species, but even until then we have to consider it as a member of the Hungarian fauna.

\section{${ }^{6}$ Haasea hungarica (Verhoeff, 1928)}

The genus Haasea has recently been comprehensively revised by Antić \& Akkari (2020). For Haasea hungarica, they listed several new localities (Lower Austria, Slovenia, Serbia, and southern Romania), hence widening its distribution over the Carpathian Basin (see map by Antić \& Akkari 2020: fig. 40). Its former endemic status to Hungary according to earlier authors (Verhoeff 1928, Szalay 1942, Korsós 1998) can now be revised. Tabacaru's subspecies (Orobainosoma hungaricum orientale Tabacaru, 1965) from the Romanian Banat is a junior subjective synonym of Haasea hungarica (Antić \& Akkari 2020).

\section{${ }^{7}$ Mastigona species}

In the former species lists, five species of the genus Mastigona (previously Heteroporatia) were recorded from present-day Hungary (Korsós 1998, 2005). Here we consider only three species as valid: M. bosniensis (Verhoeff, 1897), M. mutabilis (Attems, 1899), and M. transsylvanica (Verhoeff, 1897). The fourth, $M$. vihorlatica (Attems, 1899) was already considered as a junior synonym of $M$. bosniensis by Hauser (2004), although he did not express it explicitly, and the fifth, M. mehelyi (Verhoeff, 1897), was synonymized with $M$. bosniensis by Lazányi \& Korsós (2009). M. transsylvanica was recorded from Jósvafö, Northeast Hungary by Matic \& Ceuca (1969). 


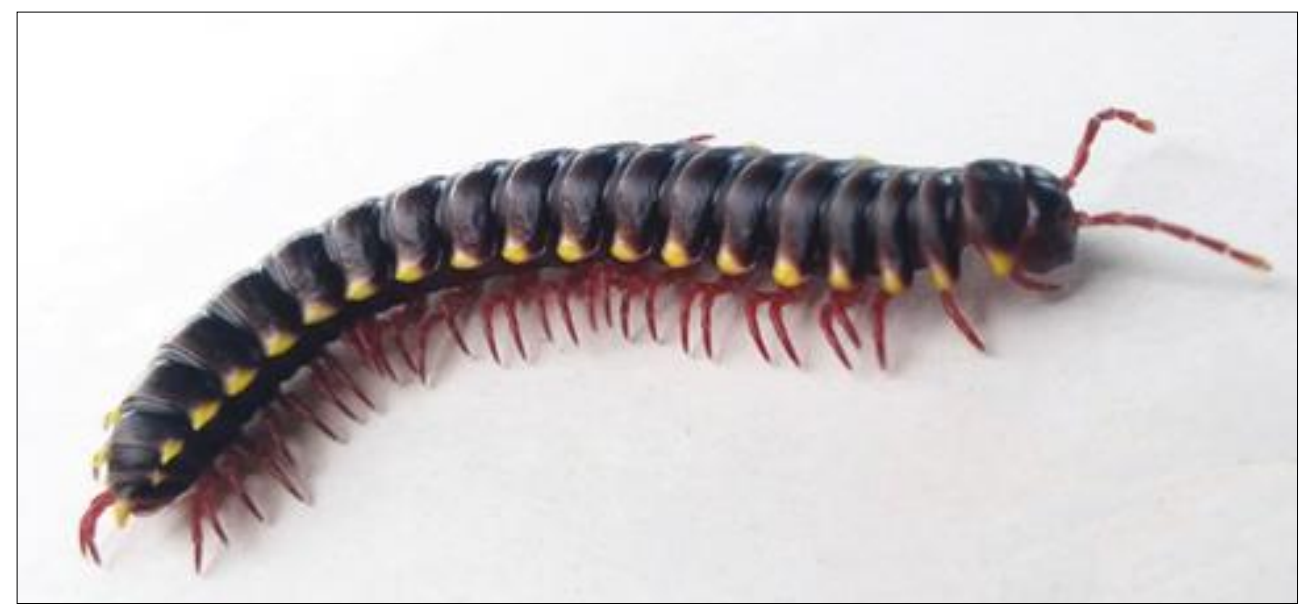

Fig. 1. Chondrodesmus riparius from Törökbálint.

\section{${ }^{8}$ Chondrodesmus riparius Carl, 1914}

(Fig. 1)

This exotic species was first found in Hungary by Benedek Török, an employee at the Plantart Horticulture in Törökbálint near Budapest in May 2015. A few specimens were seen in the pots of imported Phoenix palm. One year later a dozen specimen were recorded in an office building in Budapest by Liza Takács, spreading out also from imported indoor plant pots. These findings represent new records for the Hungarian millipede fauna.

The species was originally described from Colombia, tropical South America, and in Europe it was first found in Umeå, Sweden (2000), later in Söderköping, Sweden (2006), then in Copenhagen, Denmark and as well as in Bonn, Germany (Anderson \& Enghoff 2007, Enghoff 2008). Most probably it is distributed throughout the continent by horticultures and household megastore networks (like IKEA). It is unlikely to survive in natural environments.

\section{${ }^{9}$ Polydesmidae}

Brachydesmus dadayi Verhoeff, 1895, B. troglobius Daday, 1889, and Polydesmus schaessburgensis Verhoeff, 1898 were all dealt with as endemic species to Hungary by Korsós (1998). B. dadayi was recorded from Bulgaria already by Strasser (1973), and recently from Slovakia (Hal'ková \& Mock 2018). Distribution of B. troglobius was discussed in detail by Angyal et al. (2017) (Slovenia, Serbia and Montenegro). P. schaessburgensis was found as a new species to the fauna of Bulgaria (Bachvarova et al. 2017). With this keeping in mind, no polydesmids can now be considered as an endemic species to the Carpathian Basin.

In addition, based on a formerly omitted literature record, we here add Polydesmus subscabratus Latzel, 1884 to the Hungarian fauna. The species was mentioned already by Daday (1889) from Sátoraljaújhely, extreme northeast of Hungary, and from Velejte (= Vel'aty), southeastern Slovakia. Hal'ková \& Mock (2018), however, still handle these as unconfirmed records, until fresh specimens are collected.

Polydesmus transylvanicus Daday, 1889 was first recorded from Hungary by Kutas (2000): Szeged, Tisza-Maros rivers confluence, 5 Nov. 1996, leg. E. Hornung (3 males, 10 females, 2 juveniles). Hal'ková \& Mock (2018) also recorded it from as far as eastern Slovakia. 


\section{${ }^{10}$ REVIEW OF THE HUNGARIAN SPECIES OF BRACHYIULUS}

The genus Brachyiulus Berlese, 1884 was revised by Vagalinski \& Lazányi (2018). They gave a complete morphological redescription of the genus, and listed seven species: $B$. apfelbeckii Verhoeff, 1898, B. bagnalli (Brolemann, 1924), B. jawlowskii Lohmander, 1928, B. lusitanus Verhoeff, 1898, B. pusillus (Leach, 1815), B. stuxbergii (Fanzago, 1875) and $B$. varibolinus Attems, 1904. The distribution of the genus covers Central and Eastern Europe, the Balkans, Italy, and even the Caucasus and Kazakhstan.

Brachyiulus bagnalli was the only species hitherto reported in Hungary (Korsós 1994, 1998). However, this species was previously mentioned in the literature as B. pusillus (pl. Loksa 1956), and just later clarified to be $B$. bagnalli (Dziadosz 1964, Korsós 1994). B. lusitanus was only mentioned once from the country, in an unpublished thesis (Sziráki 1966), and remained dubious till now (Korsós 1994, 1998). According to literature distribution data (Kime \& Enghoff 2017, Vagalinski \& Lazányi 2018) three species occur in Central Europe: $B$. bagnalli, B. lusitanus, and B. pusillus. Here we give descriptive data and definite occurrences of the three species in Hungary.

All material investigated belong to the HNHM. Methods are the same as in Lazányi \& Korsós (2011).

\section{TAXONOMIC PART}

\section{Brachyiulus bagnalli (Brolemann, 1924)}

(Figs 2-3, 8-9, 14-15, 21)

Microbrachyiulus Bagnalli Brolemann, 1924: pp. 108-109.

Brachyiulus bagnalli: Schubart 1934: p. 276.

Brachyiulus pusillus ssp. Kaszabi Loksa, 1956: p. 389 , fig. 5 .

Brachyiulus pusillus: Sziráki 1966: p. 43, figs 78-79.
Brachyiulus bagnalli: Vagalinski \& Lazányi 2018: pp. 16-17.

Material investigated. Vizsoly, backwater of Hernád, 21 June 2002, leg. Hegyessy G., det. Bogyó D.; Vizsoly, backwater of Hernád, 29 July 2002, leg. Hegyessy G., det. Bogyó D.; Tarcal, Ördög mine, 15 May 1999, leg. Hegyessy G., det. Bogyó D.; Szécsény, Pöstény steppe, 7 June 2005, leg. Hegyessy G., det. Bogyó D.; Szécsény, Pöstény steppe, 30 June 2005, leg. Hegyessy G., det. Bogyó D.; Mezőzombor, Szarka farm, 5 July 2005, leg. Hegyessy G., det. Bogyó D.; Mezőzombor, Szarka farm, 1 Aug. 2006, leg. Hegyessy G., det. Bogyó D.; Szentistvánbaksa, Baksa stack, 22 May 2002, leg. Hegyessy G., det. Bogyó D.; Zalkod, Palocsa, 9 May 2002, leg. Hegyessy G., det. Bogyó D.; Közép-tiszai Landscape Protection Area, Kisköre, Patkós, willowy, 1 Apr. 1995, leg. Korsós Z., det. Korsós Z. 1995; Apaj, beneath logs, 7 Apr. 1991, leg. Farkas B., det. Korsós Z. 1994; Pusztaszeri Landscape Protection Area, Baks, Palásti forest, oak forest, 4 June 1994, leg. Z. Korsós, det. Korsós Z. 1994; County Pest, Szentendre, Northern boundary, floodplain of the Danube, 25 June 1995, leg. Korsós Z., det. Korsós Z.; County Pest, Makád, 27 Mar. 1989, leg. Merkl O., det. Korsós Z. 1989; County Pest, Szob, Danube shore, 27 Dec. 1988, leg. Korsós Z., det. Korsós Z. 1989; Budapest, Békásmegyer, Róka hill, 30 Mar. 1989, leg. Szederkényi N., det. Korsós Z. 1989; Budapest, Népsziget, $100 \mathrm{~m}$, willowy, under bark, 15 Mar. 1990, leg. Merkl O., det. Korsós Z. 1990; Budapest, Hajógyári island, willowy, leaf litter, 4 Mar. 1990, leg. Merkl O., det. Korsós Z. 1990; Budapest, Hajógyári island, 1 Apr. 1991, leg. Merkl O., det. Korsós Z. 1991; Budapest, Gellért hill, Somlói street 12, leaf litter, 10 Feb. 1998, leg. Fürjes I., det. Korsós Z.; Budapest, Gellért hill, Somlói street, 10 May 1989, leg. Fürjes I., det. Korsós Z. 1989; Fertőújlak, det. Korsós Z. 1995; Lébény, Nyíres, 30 Mar. 2000, leg. Podlussány A., det. Korsós Z.; County Somogy, Balatonszentgyörgy, Gulya Restaurant, 30 May 1994, leg. British Myriapod Group; County Somogy, Balatonfenyves, Hotel Fenyves, 29 May 1994, leg. R. E. Jones; Szeged, alluvium on the shore of Tisza, 8 Mar. 1937, leg. K. Czógler, det. Korsós Z. 1986; 
County Baranya, Drávapalkonya, floodplain, willowy, 8 Nov. 1995, leg. Korsós Z. 1995; Fertö-Hanság National Park, Mosonszolnok, Öreg forest, 11 Oct. 1995, leg. Horváth Edit, det. Korsós Z.; Tihany, 16 June 1972, Loksa material, det. Lazányi E. 2019; County Fejér, Baracska, beneath bark of fallen tree, 3 Apr. 1988, leg. Korsós Z., det. Korsós Z. 1988; Fertö-Hanság National Park, along the road leading to Nyíres, 18 Apr. 1996, leg. Horváth Edit; Budapest, Csillag hill, 30 Mar. 1990, leg.
Szederkényi N, det. Korsós 1990; Budapest, Csillag hill, 1 Feb. 1989, leg. Szederkényi N, det. Korsós Z. 1989; Budapest, Városmajor, park, 5 Apr. 1990, leg. Korsós Z., det. Korsós Z.; Budapest, Városliget, 8 Apr. 1989, leg. Korsós Z., det. Korsós Z. 1989.

\section{Descriptive notes}

Males. Length: 10.1-11.8 mm, height: 0.6$0.8 \mathrm{~mm}$; number of body rings: $33+(1-2)+\mathrm{T}$; stadium: VIII.
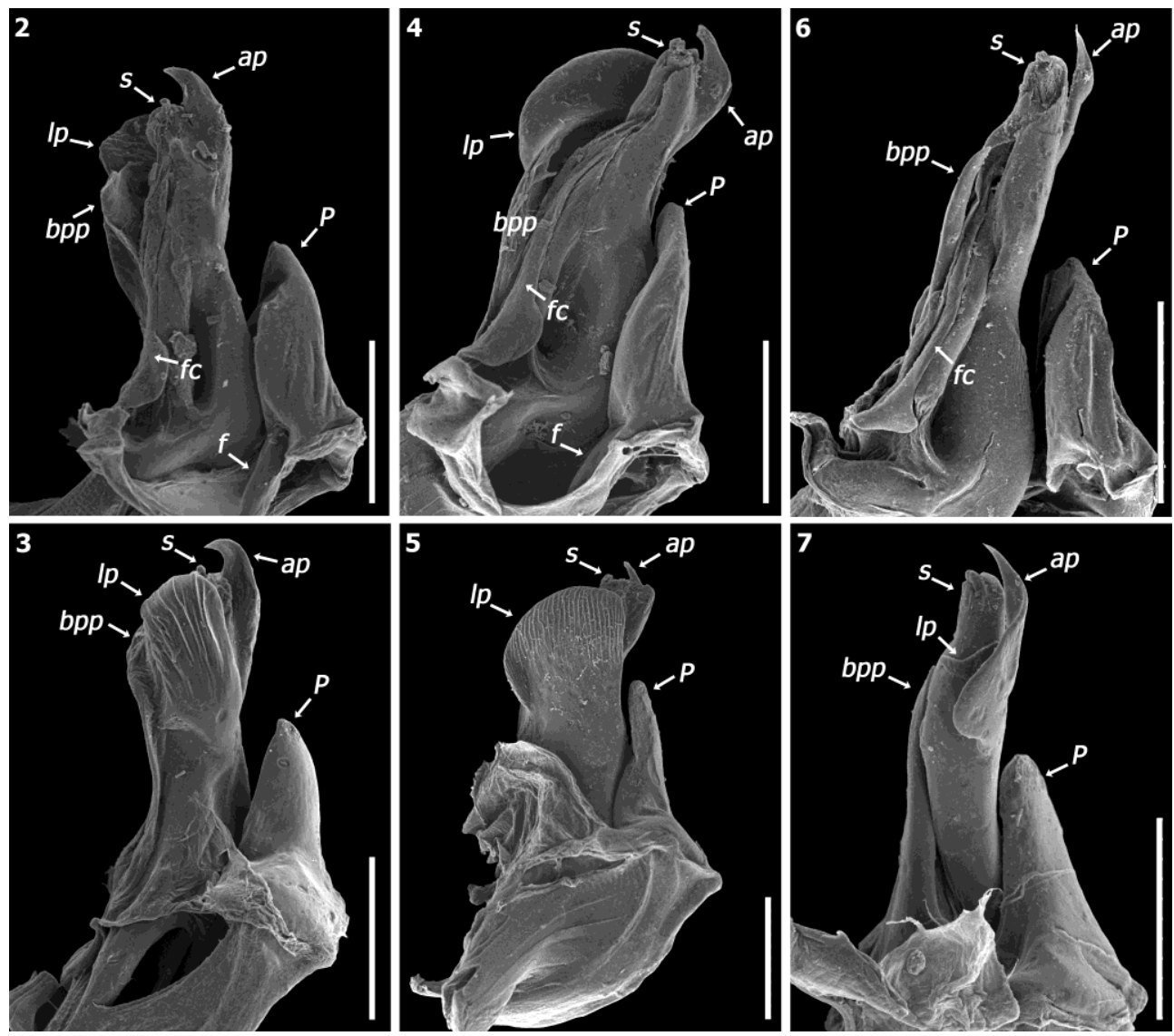

Figures 2-7. SEM figures of Brachyiulus male gonopods, from mesal (upper row) and lateral views (lower row). 2-3=B. bagnalli (County Pest, Szob, Danube shore, 27 Dec. 1988, leg. Z. Korsós), left and right gonopods, respectively, but both flipped horizontally to facilitate comparison; 4-5 = B. lusitanus (County Somogy, Balatonfenyves, 29 May 1994, leg. British Myriapod Group), right and left gonopods, respectively; 6-7 = B. pusillus (Törökbálint, Plantart Horticulture, 14 May 2015, leg. Z. Korsós), left and right gonopods, respectively, but both flipped horizontally to facilitate comparison. Abbreviations: $a p$ : anterior process, $f c$ : flagellum channel, $l p$ : lateral process, $P$ : promere, $s$ : solenomere. Scale bars: $0.2 \mathrm{~mm}$. 
Anal valves with 9-10 setae on the valve, and another 9-10 on the mesal margin of the valve. Subanal scale less pointed than in B. lusitanus.

Gonopods (Figs 2-3, 8-9): Opisthomere without mesoanterior process; lateral process $(\boldsymbol{l p})$ wide, divided into two parts: the anterolateral one forming a flattened, thin lamella with furrows, the mesocaudal part slightly pointed, without furrows.

Females. Length: 11.7-12.4 mm, height: 0.8$0.9 \mathrm{~mm}$, number of body rings: $(33-35)+(2)+\mathrm{T}$, stadium: VIII.
Prefemur and femur ( $\boldsymbol{p} \boldsymbol{f}$ and $\boldsymbol{f}$ on Fig. 15, respectively) of mature female's $2^{\text {nd }}$ leg-pair more elongated than the respective parts of $B$. lusitanus females (length/width ratio is around 1.5-1.7 for both parts).Anal valve with around 8 setae on the valve, and 8 on its mesal margin.

Vulva (Fig.14): Not as elongated as by $B$. lusitanus (length/width ratio never reaching 2). Apical opening (o) is rounded, with a conspicuous central area. Bursa apically with 10-14 (max. 18) setae, i.e. considerably less setose than $B$. lusitanus. Side sclerites $(\boldsymbol{s c})$ with 4 setae.
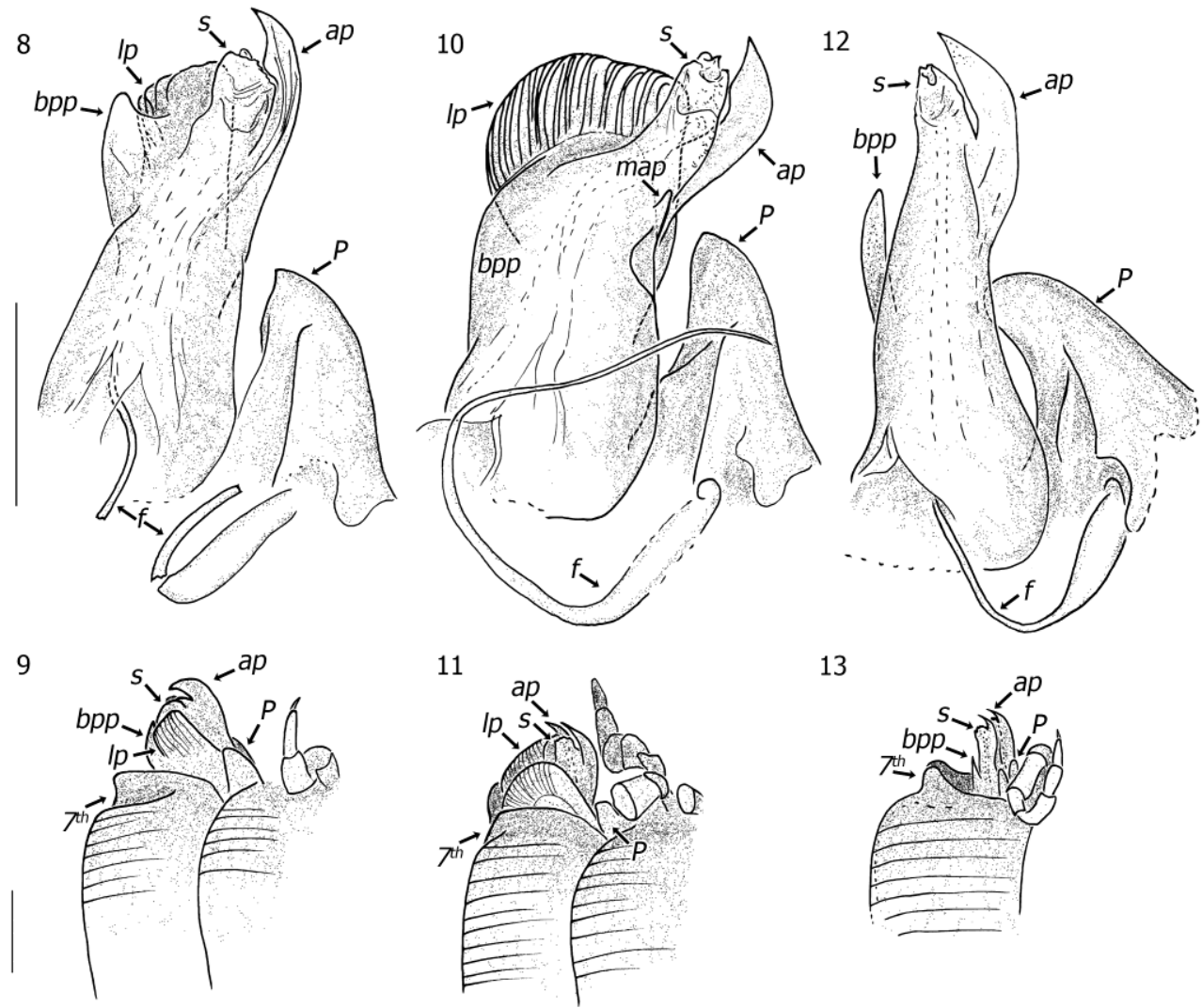

13

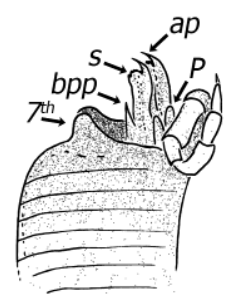

Figures 8-13. Brachyiulus male gonopods: from mesal view and in situ from left. 8-9= B. bagnalli (Budapest, Népsziget, 15 Mar. 1990, leg. O. Merkl), right gonopods, and in situ; 10-11 = B. lusitanus (Törökbálint, Plantart Horticulture, 14 May 2015 , leg. Z. Korsós); right gonopods, and in situ; 12-13 = B. pusillus (Törökbálint, Plantart Horticulture, 14 May 2015, leg. Z. Korsós), left gonopods flipped horizontally to facilitate comparison, and in situ. Abbreviations: $a p$ : anterior process, $f$ : flagellum, $l p$ : lateral process, map: mesoanterior process, $P$ : promere, $s$ : solenomere, $7^{\text {th }}$ : pleurotergite of the $7^{\text {th }}$ body ring. Scale bars: $0.2 \mathrm{~mm}$. 

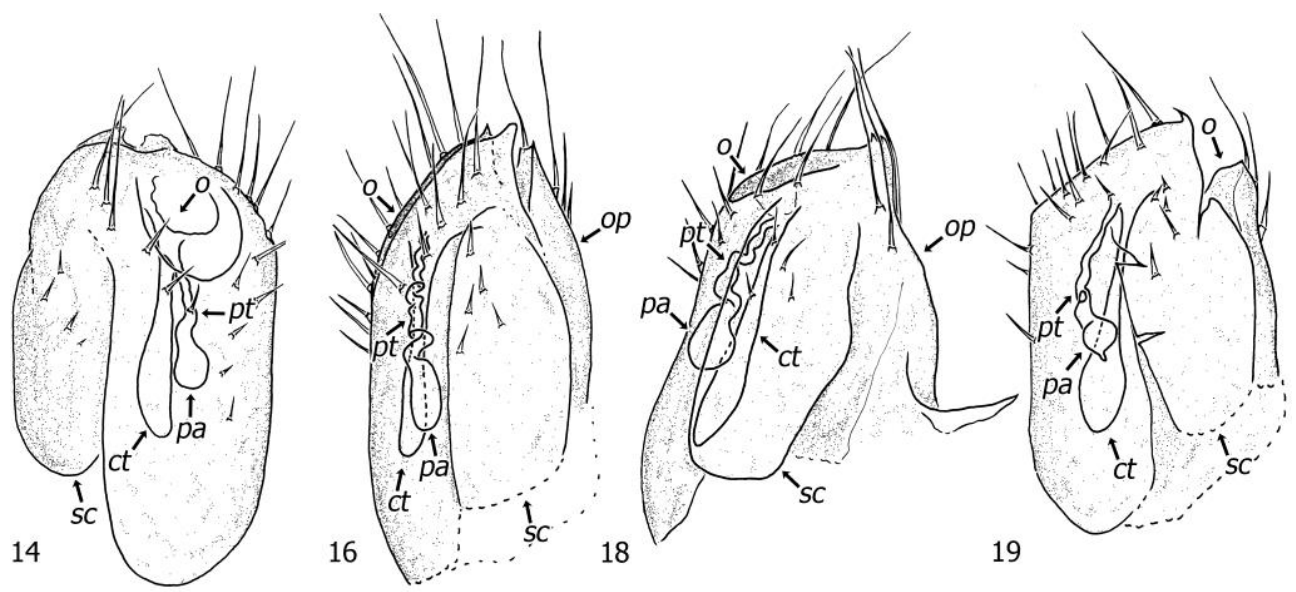

18

19
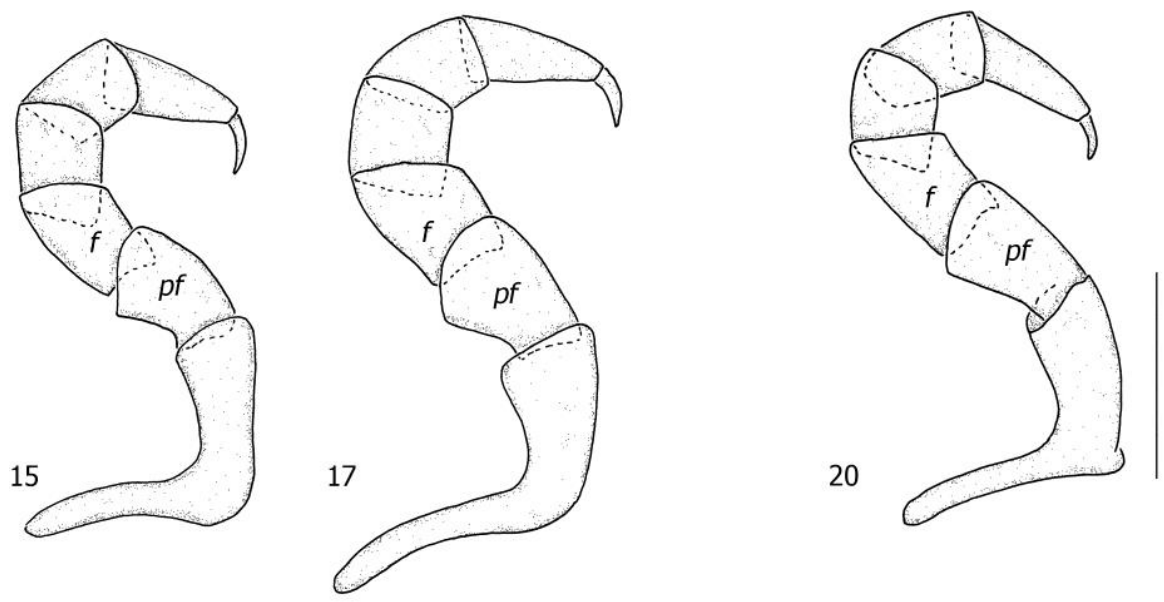

Figures 14-20. Brachyiulus vulvae and female $2^{\text {nd }}$ legs. $14-15=$ B. bagnalli (Pusztaszeri Landscape Protection Area, Baks, Palásti forest, 4 June 1994, leg. Z. Korsós), right vulva and right $2^{\text {nd }}$ leg from caudal view; $16-17=B$. lusitanus, (Szombathely, private home, Oct. 1998, leg. Cs. Szinetár), left vulva from caudo-lateral and right $2^{\text {nd }}$ leg from caudal view; $18=B$. aff. pusillus (Törökbálint, Plantart Horticulture, 14 May 2015, leg. Z. Korsós), left vulva from lateral view; $19-20=$ B. pusillus ("Microbrachyiulus litoralis Verh.” Bayern, III.3.127), left vulva from caudo-lateral view, and left $2^{\text {nd }}$ leg from caudal view but flipped horizontally to facilitate comparison. Abbreviations: $c t$ : central tube, $f$ : femur, $o$ : opening, op: operculum, $p a$ : posterior ampulla, $p f$ : prefemur, $p t$ : posterior tube, $s c$ : side sclerite. Scale bars: $0.2 \mathrm{~mm}$.

Central tube ( $\boldsymbol{c t}$ ) elongated, distally slightly widening, at least 1.5 times longer than posterior tube $(\boldsymbol{p t})$. Posterior tube $(\boldsymbol{p t})$ wavy or just slightly folded (i.e. less folded than in B. lusitanus), ending in an elongated posterior ampulla $(\boldsymbol{p a})$.

Distribution. Central European and Balkan species (Kime \& Enghoff 2017, Vagalinski \& Lazányi 2018). In Hungary it is found mostly in natural habitats (Fig. 21). However, it also occurs in rural habitats as cities, parks. In these latter places it can co-occur with B. lusitanus.

Remarks. In Hungary, this species is most similar to $B$. lusitanus at first sight. The opisthomere of $B$. bagnalli does not have a mesoanterior process as in B. lusitanus (map on Fig. $10)$, the well-developed basoposterior process is 
partly fused with the lateral process (bpp and $\boldsymbol{l p}$ on Figs 2-3, 8-9). The lateral process is thinner than in B. lusitanus.

Both males and females have around 8-10 seate on the anal valves (and 8-10 more on the mesal margin of the anal valves), not only $2-5$ (5-
6, respectively) as in B. lusitanus and B. pusillus.

Since the poor original description of $B . p u$ sillus there has been a lot of confusion about many Brachyiulus species (for discussion see Vagalinski \& Lazányi 2018). Although Brolemann (1924) corrected the misunderstanding

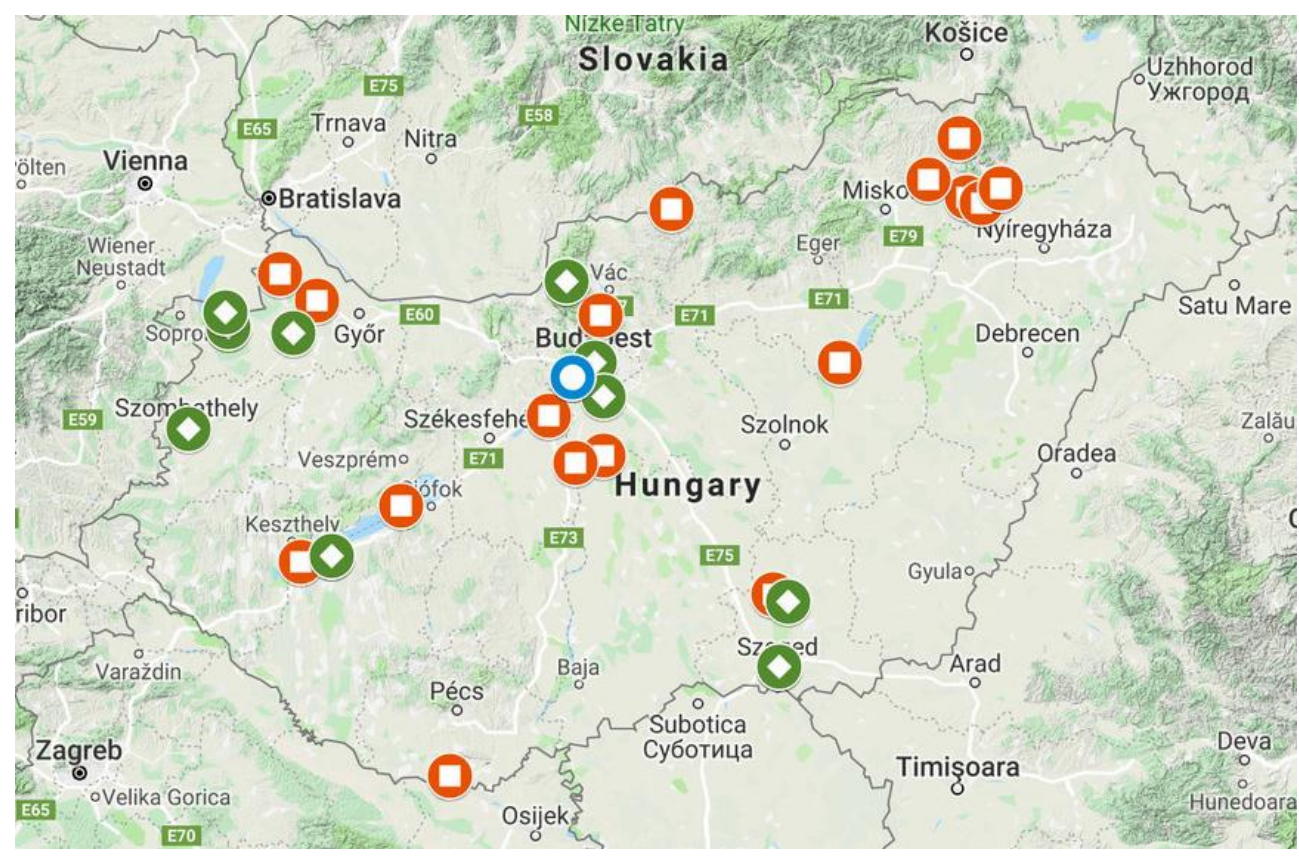

Figure 21. Distribution of three Brachyiulus species in Hungary.

, Brachyiulus pusillus

around the "Hungarian" $B$. pusillus by establishing a new name, B. bagnalli, and Dziadosz (1964) drew attention to this problem, the information did not become widely known. Loksa was still aware only of $B$. pusillus when he found the real B. bagnalli in Hungary (Loksa 1956), and therefore he described it as a new subspecies: B. pusillus ssp. Kaszabi Loksa, 1956 (later synonymised with $B$. bagnalli by Korsós 1994). As a student of Loksa, Sziráki has also referred to the species as B. pusillus (Sziráki 1966).

\section{Brachyiulus lusitanus (Verhoeff, 1898)}

(Figs 4-5, 10-11, 16-17, 21)

Brachyiulus pusillus, lusitanus (sic!) Verhoeff, 1898: pp. 153-154, fig. 28.

Brachyiulus lusitanus: Sziráki 1966: p. 42.

Brachyiulus lusitanus: Vagalinski \& Lazányi 2018: pp. 17-18, figs 6-9.

Brachyiulus bagnalli partim.: Korsós 1998: p. 90. 
Material investigated (all det. Lazányi E.). Budapest, Margitsziget, 30 Apr. 1990, leg. Merkl O.; Budapest, Népliget, 6 Apr. 1990, leg. Róka Sz. \& Korsós Z.; Budapest, Zugló, 27 Mar. 1990, leg. Korsós Z.; Budapest, Zugló, 15 Mar. 1989, leg. Korsós Z.; Budapest, Zugló, Vezér street, garden, 19 Mar. 1989, leg. Korsós Z.; Budapest, Zugló, garden, 29 Oct. 1988, leg. Korsós Z.; Budapest, 1096, Ernő street 21., inner garden, leaf litter, 19. Apr. 2019, leg. E. Lazányi; Dunaharaszti, garden, 11 Nov. 1989, leg. Sziráki Gy.; County Pest, Szob, Danube shore, 27 Dec. 1988, leg. Korsós Z.; Mindszent, Nagyhalom, 4 Oct. 1985, leg. Hornung E; Szeged, Lake Fehér, from willow, 28 Apr. 1996, leg. Korsós Z.; Csorna, Lócsi channel, 17 June 1997, leg. Horváth E.; County Somogy, Balatonfenyves, 29 May 1994, leg. British Myriapod Group; Szombathely, private home, Oct. 1998, leg. Szinetár Cs.; Fertő-Hanság, Fertöújlak, Ürgedomb, 10 Oct. 1995, leg. Podlussány A.; Törökbálint, Plantart Kft., 14 May 2015, leg. Z. Korsós; Fertô-Hanság National Park, along the road leading to Nyíres, 18 Apr. 1996, leg. Horváth E.; Budapest, Csillaghegy, 30 Mar. 1990, leg. Szederkényi N.; Budapest, Csillaghegy, 1 Feb. 1989, leg. Szederkényi N.; Budapest, Városmajor, park, 5 Apr. 1990, leg. Korsós Z.; Budapest, Városliget, 8 Apr. 1989, leg. Korsós Z.

\section{Descriptive notes}

Males. Length: 10.4-10.5 mm, height: 0.8 $\mathrm{mm}$; number of body rings: $33+2+\mathrm{T}$; stadium: VIII.Subanal scale somewhat more pointed than in B. bagnalli.

Gonopods (Figs 4-5, 10-11): Opisthomere with hardly detectable mesoanterior process (map on Fig. 10); lateral process wide, shovellike, with numerous furrows $(\boldsymbol{l p})$.

Females. Length: 11.6-15.6 mm, height:1$1.1 \mathrm{~mm}$, number of body rings: $(32-36)+(1-$ $2)+T$, stadium: VIII-IX. Prefemur and femur ( $\boldsymbol{p} \boldsymbol{f}$ and $f$ on Fig. 17, respectively) of mature female's $2^{\text {nd }}$ leg-pair more stout than the respective parts of $B$. bagnalli females (length/width ratio around $1.2-1.5$ for prefemur, and around 1.3 for femur).
Anal valve with around 2-4 setae on the valve, and 5-6 on its mesal margin. Prefemur and femur ( $\boldsymbol{p} \boldsymbol{f}$ and $\boldsymbol{f}$ on Fig. 17, respectively) of mature female's $2^{\text {nd }}$ leg-pair more stout than the respective parts of $B$. bagnalli females (length/width ratio around 1.2-1.5 for prefemur, and around 1.3 for femur).

Vulva (Fig. 16): More elongated as by $B$. bagnalli (length/width ratio around 2). Apical opening (o) a bit U-shaped, not rounded. Bursa apically with 20-26 setae, i.e. considerably more setose than $B$. bagnalli. Side sclerites (sc) with 3-5 setae. Central tube (ct) elongated, distally slightly widening, just 1.1-1.3times longer than posterior tube $(p t)$. Posterior tube $(p t)$ considerably folded, ending in an elongated or drop-shaped posterior ampulla $(\boldsymbol{p a})$.

Distribution. Subcosmopolitan species (Kime \& Enghoff 2017, Vagalinski \& Lazányi 2018). In Hungary it is also found in mostly urban, rural habitats, gardens, parks, horticultures (Fig. 21). However, occasionally it may occur in natural habitats, too.

Remarks. In Hungary this species is most similar to B. bagnalli at first sight. The opisthomere of $B$. lusitanus does have a mesoanterior process (map on Fig. 10) contrary to B. bagnal$l i$, but this process is hard to detect. The other difference is that the opisthomere's lateral process forms a wide, shovel-like lamella ( $\boldsymbol{l} \boldsymbol{p}$ on Figs 4-5, 10-11) which can be seen even in situ (Fig. 11). Basoposterior process (bpp) not so prominent. Anal valves are covered with only a few setae (2-5 on the valves and 5-6 on the anal valve's mesal margin of the valves) compared to B. bagnalli (8-10 and 8-10, respectively), but this feature does not distinguish the species from B. pusillus. Tadler gave beautiful detailed drawings about the species' gonopods and vulva and their fitting during copulation (Tadler 1996: figs. 2, 6, 9, 12 and 15). During copulation the vulva remains in the vulval sac. The short promerite touches the female's second leg-pair, while the considerably longer opisthomerite is deeply introduced to the vulval sac. The solenomerite fits into the opening (central funnel), and the apical process protrudes into the slit between the valvae (Tadler 1996). 
The species was mentioned from Hungary in the doctoral thesis of Sziráki (1966), but only as information received from Loksa by personal communication (Sziráki, pers comm.). The data presented here are the first reliable Hungarian records of the species.

\section{Brachyiulus pusillus (Leach, 1815) (Figs 6-7, 12-13, 18-20, 21)}

Julus pusillus Leach, 1815: pp. 379-380.

Brachyiulus (Microbrachyiulus) littoralis Verhoeff, 1898: Brolemann 1924: pp. 108-109.

Brachyiulus pusillus: Vagalinski \& Lazányi 2018: pp. 18-19.

Material investigated. Pest County, Törökbálint, Plantart Horticulture., 14 May 2015, leg. B. Török, det. Lazányi E. 2019; Microbrachyiulus litoralis Verh. Bayern, III.3.127.

\section{Descriptive notes}

Males. Length: $8.5-11.9 \mathrm{~mm}$, height: $0.7-1$ $\mathrm{mm}$; number of body rings: $(29-35)+(1-2)+\mathrm{T}$; stadium: VIII.Anal valves with 2-3 setae on the valve and 5-6 setae on its mesal margin. Subanal scale somewhat pointed.

Gonopods (Figs 6-7, 12-13): Opisthomere: without mesoanterior process, lateral process vestigial (lp), basoposterior process (bpp) short, thin, pointed.

Females. There were two adult B. pusillus females in the German sample (from Bayern), and three females in the Hungarian sample, but here males of both B. lusitanus and B. pusillus were found. Based on comparison with both the German (B. pusillus) and with other Hungarian material (B. lusitanus) we presume that there were $B$. pusillus females in the sample from Törökbálint. However, we give descriptive data separately for females of the two samples because the adult female individuals from Bayern were smaller, just in stadium VII.

Females from Bayern: Length: 10.2-11mm, height: $1-1.1 \mathrm{~mm}$, number of body rings: (29$31)+(2-3)+T$, stadium: VII. Anal valves with $2-$
3 setae on the valve and 5-6 setae on its mesal margin. Prefemur and femur ( $\boldsymbol{p} \boldsymbol{f}$ and $\boldsymbol{f}$ on Fig. 20 , respectively) of mature female's $2^{\text {nd }} l$ leg-pair elongated (length/width ratio around 1.6-1.62 for prefemur, and around 1.64-1.78 for femur). Vulva (Fig.19): less elongated compared to $B$. lusitanus (length/width ratio 1.63-1.7). Bursa apically with 14-16 setae, side sclerites (sc) with 2-5 setae. Central tube (ct) elongated, distally more or less widening, around 1.5 times longer than posterior tube $(p t)$. Posterior tube (pt) moderately folded, ending in a mostly drop shaped posterior ampulla $(\boldsymbol{p a})$, distally pointed.

Females from Törökbálint: Length: 11.5-14 $\mathrm{mm}$, height: $1-1.1 \mathrm{~mm}$, number of body rings: (32-36)+(1-2)+T, stadium: VIII-IX. Vulvae: Anal valves with 2-3 setae on the valve and 5-6 setae on its mesal margin. Vulva (Fig. 18): elongated (length/width ratio varies between 1.85-2.34). Bursa apically with 14-20 setae, side sclerites (sc) with 3-5 setae. Central tube (ct) elongated, distally slightly widening, around 1.4-1.5 times longer than posterior tube $(p t)$. Posterior tube (pt) moderately folded, ending in a mostly drop shaped posterior ampulla $(\boldsymbol{p a})$.

Distribution. Central and Western Europe, introduced to other regions (Kime \& Enghoff 2017, Vagalinski \& Lazányi 2018). In Hungary, the species is known only from horticulture, so its presence seems to be resulting from anthropochory (Fig. 21).

Remarks. The gonopods of this species differ significantly from those of the other two Brachyiulus species occurring in Hungary. The opisthomere is thin, elongated, its lateral process ( $\boldsymbol{l}$ on Figs 6-7, 12-13) is not lamellar, but vestigial compared to other congeneric species. The basoposterior process (bpp) is well-developed, but short, thin.Although the gonopods of $B$. pusillus are obviously different from the Hungarian congeners, female vulvae show intermediate characters between B. bagnalli and B. lusitanus.

As already mentioned in the discussion above the $B$. bagnalli section, the name " $B$. pusillus" has been erroneously cited many times from Hungary. The true B. pusillus is here reported as new to the Hungarian fauna. 


\section{CONCLUSIONS}

The millipede fauna of Hungary presently consists of 107 species, showing a mixture of European, Mediterranean, Alpine-Atlantic, Carpathian and synanthropic elements. The Carpathian Basin itself, due to its relatively well-defined situation with the surrounding mountain chains, contains a relatively high ratio of endemism in different animal groups (Varga 2018). Earlier, Korsós (1998) counted 10 species and 15 subspecies of millipedes as endemic to Hungary, i.e. $10.2 \%, 15.3 \%$, respectively (compared to the earlier 96 species number). They were believed to occur mostly in caves and relict (such as glacial) habitats. With the accumulated distribution records from the surrounding countries, however, there remained only 2 species (1.8\%), Heteracrochordum evae and Typhloiulus polypodus, both described by Loksa(1960) from the Bükk Mts, which could be considered as endemic millipedes to the Carpathian Basin. They have probably new occurrences in neighbouring Slovakia as well. Due to the taxonomical uncertainties we do not comment on the subspecific category.

At the same time, however, influences of the surrounding Carpathian Mountains, especially from the north, represented by the Slovakian Tatras, and the east by Transylvania, as well as that of the foothills of the Alps in the west of Hungary are considered as important factors when describing the composition of the millipede fauna. Altogether, 15 species (14\%) represent rare mountainous elements which are more common in the forests of the embracing mountain chains of the Carpathians. A considerable number of species are supposed to be brought into the country by the two big rivers, the Danube and the Tisza, from the west and east, respectively. And at last, synanthropic, introduced elements (13 species) also add up to $12 \%$ of the total fauna.

Acknowledgement - We would like to thank the two reviewers, Dragan Antić (Belgrade) and Boyan Vagalinski (Sofia) for their advices and comments on the manuscript.

\section{REFERENCES}

ANDERSON, G. \& ENGHOFF, H. (2007): Nyinförd mångfoting - palmbandfoting Chondrodesmus $\mathrm{cf}$. riparius. Fauna och Flora, 102(4): 2-5.

Angyal, D., MaKarov, S. E. \& Korsós, Z. (2017): Redescription of the cave-dwelling Brachydesmus troglobiusDaday, 1889 (Diplopoda, Polydesmida). Acta zoologica Academiae Scientiarum Hungaricae, 63(1): 53-70. doi: 10.17109/AZH.63.1.53.2017

ANTIĆ, D. Ž. \& AKKARI, N. (2020): Haasea Verhoeff, 1895 - a genus of tumultuous history and chaotic records - redefinition, revision of taxonomy and geographic distributions, with descriptions of two new species from Austria and Serbia (Diplopoda, Chordeumatida, Haaseidae). Zootaxa, 4798(1): 177. doi: $\underline{10.11646 / \text { zootaxa.4798.1.1 }}$

ANTIĆ, D. Ž., RAĐA, T. \& MAKAROV, S. E. (2018): Dalmatosomatidae, a new monotypic family, and Dalmatosoma agaricum gen. et sp. nov. (Diplopoda: Chordeumatida: Craspedosomatidea) from Croatia, Balkan Peninsula. Zootaxa, 4403(2): 289-306.

doi: $\underline{10.11646 / \text { zootaxa.4403.2.4 }}$

ATTEMS, C. (1899): Neues über paläarktische Myriopoden. Zoologische Jahrbücher, Abteilung für Systematik, Ökologie und Geographie der Tiere, 12: 286-336. doi: 10.5962/bhl.part.2032

BachVarova, D., VAGalinski, B., Doichinov, A. \& STOEV, P. (2017): New records of millipedes and centipedes from Bulgaria, with an annotated checklist of the Bulgarian myriapods. Zootaxa, 4263(3): 507-526. doi: $10.11646 /$ zootaxa.4263.3.4

BogYó, D. \& Korsós, Z. (2010): Cylindroiulus caeruleocinctus (Wood, 1864), new to the fauna of Hungary and its current European distribution (Diplopoda: Julida). Schubartiana, Leipzig, 4: 914.

Bogyó, D., Korsós, Z., LAZÁNYI, E. \& HegYessy, G. (2012): Millipedes (Diplopoda) from the Zemplén Mountains, Northeast Hungary, with two julid species new to the Hungarian fauna. Opuscula zoologica Budapest, 43(2): 131-145.

BrolemanN, H. W. (1924): Notes synonymiques (Myriapodes). Bulletin de la Société d'histoire naturelle de Toulouse, 52(2): 101-111. 
CEuCA, T. (1974): Noi contributii la cunosterea diplopodelor din fauna Romaniei. Studia Universitatis Babes-Bolyai, Ser. Biol., 1: 91-97.

DADAY, J. (1889): A magyarországi Myriopodák magánrajza [Monograph of the myriopods in Hungary]. Kir. M. Természettudományi Társulat, Budapest, 126 pp. + I-III. (in Hungarian, with Latin descriptions)

DzIADOSZ, C. (1964): Eine für Polen neuen Art von Tausendfüsslern, Brachyiulus bagnalli (Brolemann), (Diplopoda, Julidae). Bulletin L'Academia Polonaise des Science, 12: 207-209.

ENGHOFF, H. (2008): A large neotropical millipede in European flower pots. Bulletin of the British Myriapod \& Isopod Group, 23: 38-39.

ENGHOFF, H. (2013): Fauna Europaea: Hungarosoma bokori Verhoeff, 1928. Fauna Europaea version 2017.06. Accessed at: https://faunaeu.org/cdm_dataportal/taxon/b96d2232-77684fde-bbe0-91feeeddb638 on 21.06.2020.

HALKOVÁ, B. \& Mock, A. (2018): Upgrading knowledge on the millipedes (Diplopoda) in Slovakia - a significant contribution of winter collections. Acta Societatis Zoologicae Bohemicae, 82: 17-25.

HAuser, H. (2004): Zur Taxonomie und Systematik von Mastigona bosniensis (Verhoeff, 1897) und Mastigona vihorlatica (Attems, 1899) (Diplopoda, Chordeumatida, Mastigophorophyllidae). Entomologische Nachrichten und Berichte, 48(23): 215-218.

HoFFMAN, R. L. (1980): Classification of the Diplopoda. Muséum d'Histoire Naturelle, Genève, 237 pp.

Kime, R. D. \& ENGHOFF, H. (2017): Atlas of European millipedes 2: Order Julida (Class Diplopoda). European Journal of Taxonomy, 346: 1-299. doi: $10.5852 /$ ejt.2017.346

KoRsós, Z. (1994): Checklist, preliminary distribution maps, and bibliography of millipedes in Hungary (Diplopoda). Miscellanea zoologica hungarica, 9: 29-82.

KoRsós, Z. (1998): Status and directions of faunistic and taxonomical research of millipedes in Hungary. Folia historico-naturalia Musei Matraensis, 22: 85-98. (in Hungarian with English summary)

Korsós, Z. (2001): Catalogue of millipedes of Somogy county (Diplopoda). In: ÁBRAHÁM, L. (ed.): Fauna catalogue of Somogy County. Natura Somogyiensis 1. Somogy Megyei Múzeumok
Igazgatósága, Kaposvár, pp. 49-56. (in Hungarian with English summary)

Korsós, Z. (2005): The millipede fauna (Diplopoda) of Hungary: a zoogeographical account. Abstracts of lectures and posters, $13^{\text {th }}$ International Congress of Myriapodology, 25-29 July 2005, Bergen, Norway, p. 24.

Korsós, Z. \& LAZÁNYI, E. (2019): Millipede fauna of Hungary: present status. In: DÁNYI, L., KoRsós, Z. \& LAZÁNYI, E. (eds): 18th International Congress of Myriapodology. Program and Abstracts. Hungarian Natural History Museum \& Hungarian Biological Society, Budapest, p. 42. [abstract] https://18icm.nhmus.hu/sites/default/file s/documents/18ICM_program\%20and\%20abstrac ts online\%20version.pdf

LAZÁNYI, E. \& Korsós, Z. (2009): Millipedes (Diplopoda) of the Aggtelek National Park, northeastern Hungary. Opuscula Zoologica Budapest, 40(1): 35-46.

LAZÁNYI, E. \& Korsós, Z. (2010): Megaphyllum silvaticum (Verhoeff, 1898) (Diplopoda: Julida), a new species to the Hungarian millipede fauna, with notes on the status of $M . \quad s$. discolor (Verhoeff, 1907) and on their relationship to $M$. projectum Verhoeff, 1894. Opuscula Zoologica Budapest, 41(1): 39-46.

LAZÁNYI, E. \& KoRsós, Z. (2011): Revision of the Megaphyllum projectum Verhoeff species complex (Myriapoda: Diplopoda: Julida: Julidae). Zootaxa, 2864: 43-56. doi: $\underline{10.11646 / \text { zootaxa.2864.1.3 }}$

LOKSA, I. (1956): The diplopod and chilopod faunas of the environs Lake Velence. Annales historiconaturales Musei nationalis hungarici, 5: 385-390.

LOKSA, I. (1960): Zwei neue Diplopoden-Arten aus Ungarn. Acta zoologica Academiae Scientiarum Hungaricae, 6: 413-418. (in German)

LOKSA, I. (1968): Einige Diplopodenformen aus Ungarn. Opuscula Zoologica Budapest, 8(1): 57-62.

Matic, Z. \& CeuCA, T. (1969): Beiträge über die Myriapoden (Chilopoda und Diplopoda) der Fauna der Ungarischen Vr. Studia Universitatis Babes-Bolyai, Seria Biologia, 14: 105-110.

Mock, A., Halková, B. \& TAjovskÝ, K. (2019): Unique external morphology of millipedes of the family Trachygonidae (Diplopoda, Chordeumatida): Case study on Heteracrochordum evae (Loksa, 1960). In: DÁNYI, L., Korsós, Z. \& 
LAZÁNYI, E. (eds): 18th International Congress of Myriapodology. Program and Abstracts. Hungarian Natural History Museum \& Hungarian Biological Society, Budapest, p. $46 . \quad$ [abstract] https://18icm.nhmus.hu/sites/default/files/docume nts/18ICM program\%20and\%20abstracts online \%20version.pdf

Mock, A., KovÁc, L., LuPTÁciK, P. \& TAJOvsKÝ, K. (2002): Najväcší troglobiont slovenských jaskýn. [The greatest troglobiont of Slovak caves.] Aragonit 7(12): 32-34. (in Slovakian)

Mock, A., TAjovský, K., Žurovcová, M., ANGYAL, D. \& KoCOUREK, P. (2014): Hungarosoma bokori Verhoeff, 1928 (Diplopoda, Chordeumatida), a tiny and enigmatic millipede: Redescription and new light to its systematics, ecology and biogeography. In: TUF, I. H. \& TAJOVSKÝ, K. (eds): Book of Abstracts, 16th International Congress of Myriapodology. 20-25 July 2014, Olomouc, Czech Republic, p. 58.

Mock, A., TAJOvSKÝ, K., ŽUrovcovÁ, M., JAROŠOVÁ, A., Kocourek, P., Gruber, J., Angyal, D. \& SPELDA, J. (2016): Hungarosoma bokori Verhoeff, 1928 (Diplopoda: Chordeumatida): new insights into its taxonomy, systematics, molecular genetics, biogeography and ecology. Zootaxa, 4178(2): 234-256. doi: 10.11646/zootaxa.4178.2.4

MRŠIĆ, N. (1987): Genus Ochogona Cook 1895 (Craspedosomatidae, Diplopoda) of Yugoslavia. Glasnik Prirodnjačkog Muzeja u Beogradu, Serija B, Bioloske nauke, 42: 51-74.

SchuBART, O. (1934): Tausendfüßler oder Myriapoda. I: Diplopoda. Die Tierwelt Deutschlands und der angrenzenden Meeresteile, 28: 1-318.

SHEAR, W. (2011): Class Diplopoda de Blainville in Gervais, 1844. In: ZHANG, Z.-Q. (ed.): Animal biodiversity: An outline of higher-level classification and survey of taxonomic richness. Zootaxa, 3148: 159-164. doi: $10.11646 /$ zootaxa.3148.1.32

SIERWALD, P. \& SPEldA, J. (2018): MilliBase: Hungarosoma bokori Verhoeff, 1928. Accessed at: http://millibase.org/aphia.php?p=taxdetails\&id=9 35138 on 21.06 .2020 .

STRASSER, K. (1973): Über Diplopoden Bulgariens, III. Annales zoologici, 30(15): 411-470.

SzALAY, L. (1942): Beiträge zur Kenntnis der Diplopoden-Fauna des Köszeger Gebirges (Adatok a Kőszegi-hegység ezerlábú [Diplopoda] faunájának ismeretéhez). Matematikai és Természe- ttudományi Értesítő, 61: 400-415. (in German andHungarian)

SZALAY, L. (1944): Beiträge zur Kenntnis der Diplopoden- und Chilopoden-Fauna Ungarns. Fragmenta faunistica hungarica, 7: 59-60.

SZIRÁKI, GY. (1966): Key to the female Diplopods in Hungary. University doctoral thesis, Eötvös Loránd University, Budapest, 52 pp. (in Hungarian)

TABACARU, I. (1965): Orobainosoma hungaricum orientale n. ssp. (Diplopoda, Ascospermophora) si dezvoltarea sa postembrionara. Lucrarile si Institutul Speologie “E. Racovitza”, 4: 229-243. (in Romanian)

TADLER, A. (1996): Functional morphology of genitalia of four species of julidan millipedes (Diplopoda: Nemasomatidae; Julidae). Zoological Journal of the Linnean Society, 11: 83-97. doi: 10.1111/j.1096-3642.1996.tb01263.x

VAGALINSKI, B. \& LAZÁNYI, E. (2018): Revision of the millipede tribe Brachyiulini Verhoeff, 1909 (Diplopoda: Julida: Julidae), with description of new taxa. Zootaxa, 4421(1): 1-142. doi: $\underline{10.11646 / \text { zootaxa.4421.1.1 }}$

VAgalinski, B., StoeV, P. \& EnGHOFF, H. (2015): A review of the millipede genus Typhloiulus Latzel, 1884 (Diplopoda: Julida: Julidae), with a description of three new species from Bulgaria and Greece. Zootaxa, 3999(3): 334-362. doi: $\underline{10.11646 / \text { zootaxa.3999.3.2 }}$

VARGA, Z. (2018): Állatvilág [Fauna]. In: KocsIs, K. (ed.): Magyarország nemzeti atlasza. Természeti környezet. [National Atlas of Hungary. Natural Environment.] Hungarian Academy of Sciences, Budapest, pp. 104-111. (in Hungarian)

VERHOEFF, K.W. (1899a): Beiträge zur Kenntniss paläarktischer Myriopoden. VIII. Aufsatz: Zur vergleichenden Morphologie, Phylogenie, Gruppen- und Art-Systematik der Chordeumiden. Archiv für Naturgeschichte, 65(1): 95-154.

VERHOEFF, K.W. (1899b): Beiträge zur Kenntniss paläarktischer Myriopoden. IX. Zur Systematik, Phylogenie und vergleichenden Morphologie der Juliden und über einige andere Diplopoden. Archiv für Naturgeschichte, 65(1-2): 183-230.

VERHOEFF, K.W. (1928): Zur Kenntnis der Diplopodenfauna Ungarns. 109. Diplopoden-Aufsatz (Adatok Magyarország Diplopoda-faunájához. 109. Diplopoda-közlemény). Állattani Közlemények, 25: 124-126, 182-199. (in German and Hungarian) 